\author{
Mariusz Nepelskia)*, Jarosław Struniawskib) \\ a) The Main School of Fire Service / Szkoła Główna Służby Pożarniczej \\ b) Police Academy in Szczytno / Wyższa Szkoła Policji w Szczytnie \\ Corresponding author / Autor korespondencyjny: mariusznepelski@gmail.com
}

\title{
A Simulator Supporting the Training of Police Officers who Process Traffic Incident Scenes
}

\section{Symulator wspomagający szkolenie funkcjonariuszy Policji w zakresie realizacji działań w miejscu wypadku drogowego}

\begin{abstract}
Aim: A simulator supporting the training of police officers who process traffic incident scenes is a tool with which we will be able to train traffic police officers in processing traffic incident scenes. The essence of the research and development project presented in this article is providing the trainee with a simulated experience of being at both typical and unusual traffic incident scenes, including those involving mass-casualty incidents, major traffic accidents, or other crisis situations. The simulator will connect the virtual world with the real world, taking the trained person into the virtual world (visualisation of the scene), and allowing he or she to process the scene (visual inspection of the scene, producing reports, providing first aid to victims, etc.). Currently, there are no comprehensive solutions supporting the training process in the proposed way. The implementation of such a tool in the Police training system will allow to improve the quality of traffic-police training, and increase the effectiveness of scene processing.

Methodology: The review was prepared on the basis of project documentation and current statistical data on traffic incidents, and selected literature on the subject. We analysed traffic incidents in the last ten years, with particular attention devoted to the number of fatalities and the number of traffic incidents. We demonstrated the complexity of the processing effort by Police officers at the scene, as well as the need to use new technologies for the purposes of training policemen, including in particular simulation systems.

Conclusions: The article addresses one of the most important tasks of the Police - which is ensuring road safety - by proving the need to use training simulators in training traffic policemen. By commissioning the construction of the simulator described in the article, the Police confirmed the need to develop the training space using the described tool. Based on the synthetic review of project documentation, we were able to confirm that the implementation of the simulator in the Police education system would allow to improve the quality of training traffic police officers, and could have a positive impact on their work environment.

Training people with the use of simulation systems eliminates property damage, and reduces the risk of loss of life and health.

Keywords: safety, Police, traffic incident, road collision, visual inspection, simulator

Type of article: original scientific article
\end{abstract}

Received: 07.11.2019; Reviewed: 16.12.2019; Accepted: 19.12.2019;

Authors` ORCID IDs: Mariusz Nepelski - 0000-0002-4183-8809; Jarosław Struniawski - 0000-0001-9671-2317;

The authors contributed the equally to this article;

Please cite as: SFT Vol. 54 Issue 2, 2019, pp. 90-97, https://doi.org/10.12845/sft.54.2.2019.6;

This is an open access article under the CC BY-SA 4.0 license (https://creativecommons.org/licenses/by-sa/4.0/).

\section{ABSTRAKT}

Cel: Symulator wspomagający szkolenie funkcjonariuszy Policji w zakresie realizacji działań w miejscu wypadku drogowego to narzędzie, dzięki któremu będzie możliwe przygotowanie funkcjonariuszy Policji do wykonywania czynności na miejscu zdarzenia drogowego. Istotą projektu badawczo-rozwojowego przedstawionego w artykule jest możliwość "przeniesienia” osoby szkolonej do miejsca typowego i nietypowego wypadku drogowego, takiego jak masowe wypadki komunikacyjne, katastrofy w ruchu lądowym lub inne sytuacje kryzysowe. Symulator połączy świat wirtualny ze światem rzeczywistym, tj. umożliwi przeniesienie szkolonej osoby do świata wirtualnego (wizualizacja miejsca zdarzenia), umożliwiając jednocześnie wykonywanie czynności w miejscu zdarzenia (inspekcja wizualna miejsca zdarzenia, opracowanie dokumentacji z przeprowadzonych czynności, udzielanie pierwszej pomocy ofiarom wypadku drogowego, itp.). Obecnie nie ma kompleksowych rozwiązań wspierających proces szkolenia w proponowany sposób. Implementacja takiego narzędzia do systemu szkolenia Policji pozwoli na podniesienie poziomu i jakości szkolenia funkcjonariuszy policji drogowej oraz zwiększenie efektywności działań podejmowanych na miejscu zdarzenia drogowego.

Projekt i metody: Artykuł został przygotowany na podstawie dokumentacji projektu i aktualnych danych statystycznych dotyczących wypadków drogowych oraz wybranej literatury przedmiotu. Przeanalizowano wypadki drogowe w ciągu ostatnich dziesięciu lat, ze szczególnym uwzględnieniem 
liczby ofiar śmiertelnych i liczby wypadków drogowych. Wykazano złożoność działań podejmowanych przez funkcjonariuszy Policji w miejscu zdarzenia drogowego, a także potrzebę zastosowania nowych technologii - zwłaszcza systemów symulacyjnych w procesie szkolenia policjantów.

Wnioski: W artykule autorzy odwołują się do jednego z najważniejszych działań Policji, jakim jest bezpieczeństwo ruchu drogowego, dowodząc konieczności użycia symulatorów szkoleniowych w szkoleniu policjantów ruchu drogowego. Policja, przyjmując rolę gestora i ubiegając się o budowę symulatora opisanego w artykule, potwierdziła potrzebę opracowania przestrzeni szkoleniowej przy użyciu wspomnianego narzędzia. Na podstawie syntetycznego przeglądu dokumentacji projektowej potwierdzono, że wdrożenie symulatora w systemie edukacji Policji pozwoli poprawić jakość szkolenia funkcjonariuszy policji drogowej i może pozytywnie wpłynąć na środowisko pracy tej formacji.

Słowa kluczowe: policja, ochrona, kontrola wzrokowa, wypadek drogowy, kolizja drogowa

Typ artykułu: oryginalny artykuł naukowy

Przyjęty: 07.11.2019; Zrecenzowany: 16.12.2019; Zaakceptowany: 19.12.2019;

Identyfikatory ORCID autorów: Mariusz Nepelski - 0000-0002-4183-8809; Jarosław Struniawski - 0000-0001-9671-2317;

Autorzy wnieśli równy wkład merytoryczny w powstanie artykułu;

Proszę cytować: SFT Vol. 54 Issue 2, 2019, pp. 90-97, https://doi.org/10.12845/sft.54.2.2019.6

This is an open access article under the CC BY-SA 4.0 license (https://creativecommons.org/licenses/by-sa/4.0/).

\section{Introduction}

In the 21 st century transport and mobility play an important role in people's lives. Modern society is characterised by increasing mobility. However, the systematic increase in the number of motor vehicles inevitably leads to a large number of traffic incidents [1-2], resulting in casualties, including fatalities, because each traffic participant is exposed to a potential danger [3-4].

Due to economic development, Poland and most other European countries suffer enormous social and economic losses.

Although various measures taken to improve road safety - such as the improvement of road infrastructure, the tightening of road traffic regulations, organisational and educational efforts - have resulted in fewer accidents and casualties, the number of traffic incidents in Poland is still large [5] (in comparison to corresponding statistics in other European countries). The problem of the road traffic accident rate has grown into an epidemic - today, it is one of the most important issues of public safety policy [6]. The analysis of the state of road safety shows [7] that despite numerous public awareness campaigns and modernised safety systems, Polish roads are still not among the safest [8]. The gravity of the problem continues to be underestimated, and the adopted principle of dispersed collective responsibility results in a low effectiveness of institutional efforts [9].

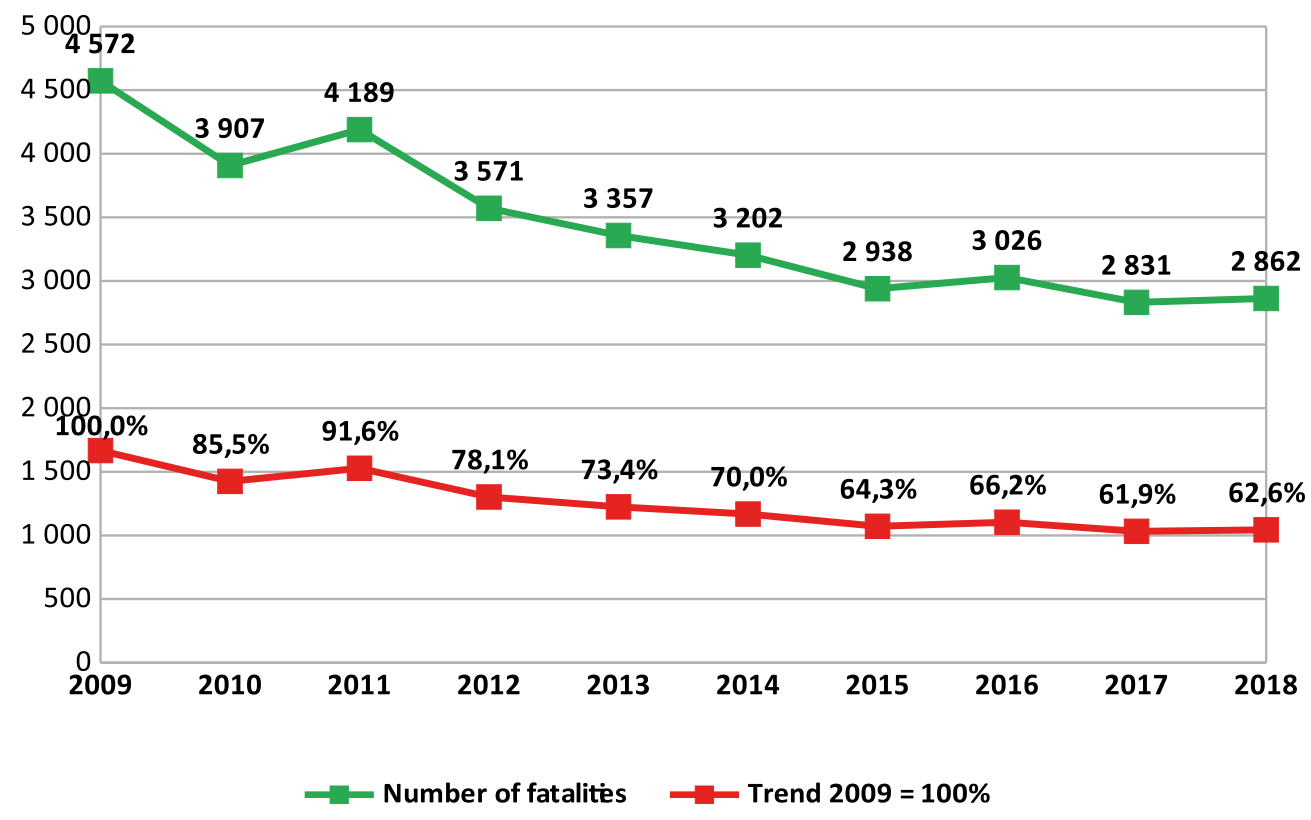

Figure 1. The number of fatalities in Poland in the years 2009-2018

Source: Statistics of the National Police Headquarters. 


\section{Characteristics of traffic incidents}

From a practical point of view, the statutory statistical classification of traffic incidents into accidents (Article 177 of the Polish Criminal Code ("CC")) and road collisions (Article 86 of the Polish Code of Petty Offences ("CPO"), Article 98 CPO or 97 CPO in conjunction with Article 39 of the Traffic Law Act) is a proper and desirable solution, as it enables their proper recording [3] and the evaluation of effectiveness of preventive measures. Article 173(1) of the CC also defines the characteristics of the offence of a major traffic accident. It should be noted that the result of such an accident is a threat to the life or health of many people, or to property of large sizes, and includes train collisions, where several people are killed and several dozen injured. In turn, police regulations [10] define a road traffic accident as a traffic accident resulting in a person being killed or injured.

Road collision, on the other hand, is a traffic incident involving only property damage. This concept differs from the concept of accident in that it involves no casualties, but only property damage, e.g. destruction of a building, vehicle, utility/telephone poles, road furniture (signs, signalling devices, bars or traffic barriers), viaducts, gates, fences and other objects.

The occurrence of a traffic accident is influenced by a set of risk factors that affect the level of road safety [11]. These factors include: people as road users (pedestrians, vehicle drivers and other people in or on a vehicle on the road), roads, vehicles, and traffic and incidental factors.

There is no doubt, however, that the majority of traffic accidents occur as a result of specific behaviours of traffic participants, resulting from their ignorance or disrespect for traffic regulations.
People as the main factor in the road dynamic [1] (drivers of motor vehicles, as well as motorcycles) contribute to accidents mostly by: driving at a speed that is excessive or inappropriate to road conditions; failure to yield the right of way to another vehicle; failure to maintain a safe distance between vehicles (misjudging distances and the vehicle stopping distance); incorrectly performing the overtaking manoeuvre. Failure to give right of way to pedestrians on pedestrian crossings is also a serious problem [12]. Another factors involves the psychomotor state of the driver (e.g. fatigue - a state of the organism which negatively affects the ability to perform work, impairs concentration; an illness). Road safety is also affected by a low level of safety devices usage (failure to wear seatbelts, non-functional air bags, unregulated headrests on the front and rear seats, failure to use child safety seats, failure to mount baby seats in a rear-facing position). The most common offence leading to an accident involves pedestrian intrusion, or crossing the road illegally. A significant problem on Polish roads are intoxicated road users and drivers of vehicles under the influence of other psychoactive substances.

Another element that has a significant impact on road safety are weather conditions. The most important atmospheric phenomena include: rainfall, snowfall, fog, strong and gusty wind, atmospheric temperatures (especially below zero), the location of the sun (driving against the sun) and lighting, the latter being dependent on the time of day and the season. The analysis of traffic accidents shows that the most tragic events occur in good weather conditions on straight sections of the road. Such circumstances increase driving comfort and the drivers develop higher speeds, resulting in more tragic consequences in the case of an accident.

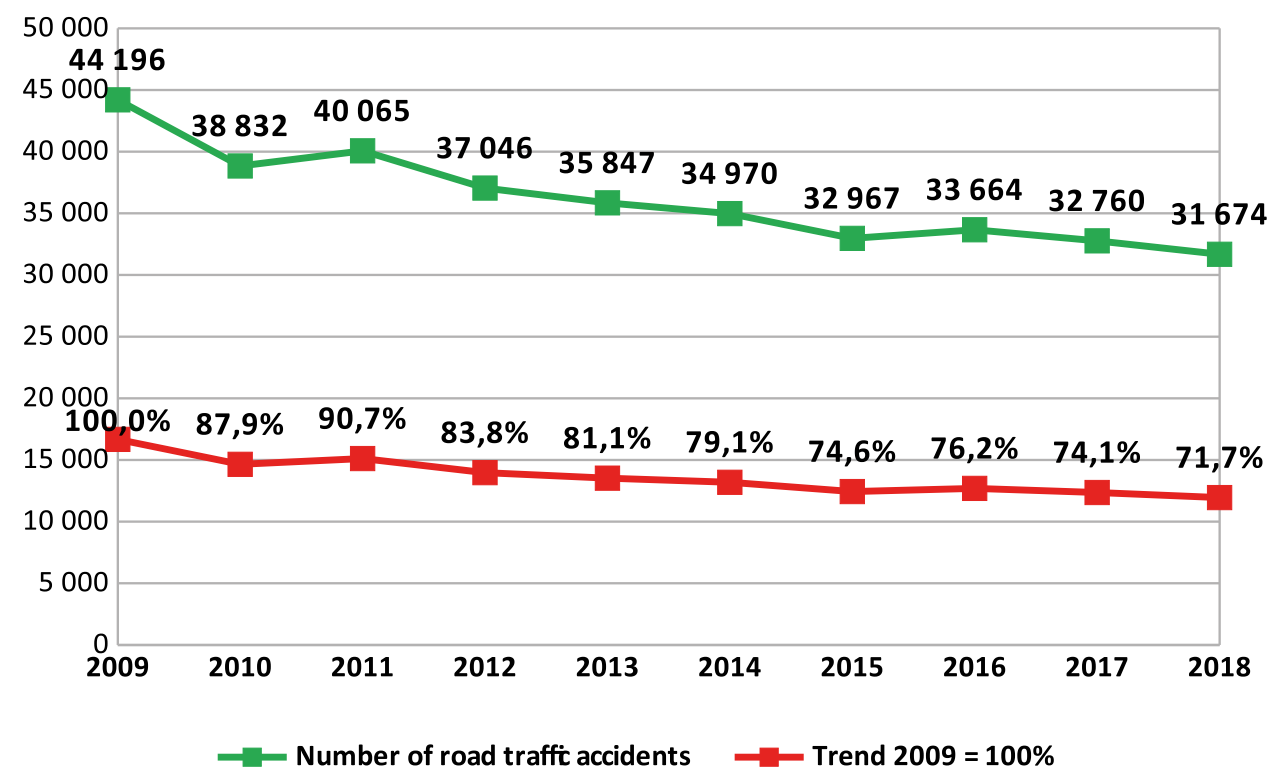

Figure 2. Road traffic accidents in Poland in the years 2009-2018

Source: Statistics of the National Police Headquarters. 
Road safety is also influenced by technical factors, which include a low quality of road infrastructure and poor condition of vehicles.

\section{Police tasks related to handling traffic accidents}

Improvement of road safety requires many entities and institutions to conduct multipronged efforts aimed at the systematic improvement of the level of road traffic safety [6]. The main tasks in this area are imposed, among others, on the Police, and focus on: traffic management and control (inspection of the condition of motor vehicles, control of dangerous goods transport, control of compliance with obligations or conditions of road transport, use of measuring and control devices for measuring speed); preventing, combating and conducting proceedings concerning road traffic offences; initiating and coordinating crime prevention programmes and handling traffic accidents.

In the event of a traffic accident, just like in any other case of a breach of public safety and order, and a threat to life, health and property, every police officer who is the first to arrive at the scene of the incident has a duty to intervene. The particular activities of a police officer in this respect are defined in the procedures set out in Ordinance No. 30 of the National Police Commander-in-Chief of 22 September 2017 on performing duties on roads. They indicate the necessity of performing activities including (§ 29.1): securing the scene of the traffic accident in order to avoid another traffic accident, and organising road traffic in the new circumstances; providing first aid to the injured; securing the scene of the traffic accident by protecting forensic evidence from loss or distortion to enable criminal proceedings; determining participants in, and witnesses to, the traffic accident; undertaking a pursuit if the perpetrator of the traffic accident has fled from the scene; determining injuries suffered by the casualties and the place of their hospitalisation.

After the traffic accident service crew (police officers from the organisational unit responsible for road traffic) or the criminal investigation group arrive at the scene, the police officer provides information about the activities performed and the facts established. Then, a visual inspection of the scene, objects and persons involved is performed, and where urgently needed - an external inspection of the corpses. Furthermore, the criminal proceedings are documented through, in particular. an inspection report [13] with a forensic sketch of the scene of the accident to scale, an official memo and a traffic accident card, as well as photographic or video documentation. When taking pictures of the evidence, attention must be paid to the following: traces visible on the road, skid marks, damage to vehicles, broken glass on the road, especially from headlights, broken off fragments of vehicles, and oil, fuel and blood spots. The documentation of all these processing activities should reflect all the facts established at the scene.

The aim of the reconstruction of a traffic accident (collision) is to reconstruct how individual events were related to each other in a sequence. In order to reconstruct these interrelations, all the facts must be gathered and classified as causes or effects.
Causes include all the events occurring before the accident/collision, e.g. the condition of the car, the speed of the car before braking, the type and condition of the pavement, weather conditions, driver's abilities (skills, physical and mental state). Effects include all the events that occurred after the collision, e.g. the degree of injury to car users or pedestrians involved in the collision and the scope of damage to the car. It is also important to determine the time intervals at which the events classified as causes and effects had occurred. These may be events occurring immediately before or after the collision, and events occurring at a bigger time interval from the moment of the collision. Classification according to the time of occurrence and the determination of the interrelations between the two groups of events are very helpful for the reconstruction of the collision and its proper analysis [14].

\section{Training of police officers in processing traffic accident scenes with the use of simulation systems}

The Police's efforts to improve road traffic safety, on the one hand, and the number of traffic accidents, on the other, make it is necessary to have highly specialised personnel processing the scene of such incidents.

In order to handle the processing effectively and according to the rules and procedures of the Police, the officers must constantly improve their skills. The legal regulations and the techniques and tactics adopted when processing traffic accidents constitute an element of professional training and development courses. Only systematic development allows officers to master the ability to make the right decisions and to perform effective and, most importantly, safe interventions.

Professional development of police officers includes: centralised training - organised by police schools and the Police Academy in Szczytno; local training - organised by organisational units of the Police or their organisational units, and external training - organised by third parties. In the area in question, the Specialist Road Traffic Training Course - General Part [15] (Decision No. 295 of the Chief Commander of the Police, 2018) is the prevailing type of such professional training. The aims of the courses include, among others, acquiring the knowledge and skills which prepare police officers to: make the legal classification of traffic accidents, secure the scene of the traffic accident, characterise forensic evidence which may be found at the scene, perform visual inspection of the scene, perform visual inspection of the vehicle, prepare photographic documentation from the inspection of the scene and vehicle, prepare a sketch and a diagram of the scene, and draw conclusions on the basis of forensic evidence.

\section{Material and methods}

Modern road traffic hazards make the Police look for new, alternative training solutions, including those which utilise advanced information technologies. The "Simulator Supporting Training of Police Officers Processing the Scene of a Traffic 
Accident" is an example of this. It is connected with the priority set by the Chief Commander of the Police, i.e. to support Police activities aimed at improving road traffic safety.

Due to the high level of detail and a wide range of scenarios and variants adapted to the specific nature of Police operations and tactics, and regulations and procedures applicable in Poland, the proposed system will be able to properly support the process of training and development of officers. The complementary training tool will make it possible to practice, in real-time, handling events that may occur when on duty in actual intervention locations. The aim of training on the simulator will be to efficiently raise and maintain a high level of officers' skills in developing the right responses in the decision making process when performing a specific task. Such solutions will make it possible to reflect scenarios of real actions taken by one or more police officers (dealing with road traffic) in the virtual world of a computer training system. A very important element of this solution, besides its innovative technical features, are the properly selected scenarios and variants of the course of events, developed from many years of police experience.

\section{Results}

The project is expected to provide a "simulator supporting training of police officers in processing the scene of a traffic accident". The simulator is a tool with which we will be able to train traffic police officers to process the scene of both typical and unusual traffic accidents, such as mass-casualty incidents, major road traffic accidents, or other crisis situations. The simulator will connect the virtual world with the real world, i.e. taking the trained person into the virtual world (visualisation of the scene) while allowing the processing of the scene (visual inspection of the scene, documentation, providing first aid to casualties, etc.).

The simulator will meet the following requirements:

1. It will enable changes of:

- seasons (summer and winter);

- time of day (day, night, dawn and dusk);

- atmospheric conditions (rain or snowfall, icing on road surfaces, as well as haze and smoke with different levels of intensity, wind speed and its direction, etc.).

2. It will contain the necessary elements of road infrastructure, including: various types of road intersections, including intersections with tracks for railway vehicles, grade-separated road junctions, tunnels, bridges, viaducts, railway crossing: tram and railway track crossings (guarded and unguarded), pedestrian crossings, bus stops, parking lots, manoeuvring areas, loading ramps, airports with runways.

3. It will simulate the behaviour of road users, i.e.: drivers of passenger cars, trucks and semi-trailer trucks, special-purpose vehicles, agricultural tractors, buses, tank trucks, privileged vehicles, motorcycles, trams, trains, as well as cyclists, pedestrians, wild animals of various sizes (deer, boar), pets (dogs).
4. It will provide access to plane crash and water traffic accident locations.

5. It will have experimentally validated models of the dynamics of passenger or delivery cars, trucks, buses and tanker vehicles, allowing the simulation of events as close to real conditions as possible, and also their use for research purposes. Such a quality of models is necessary for the system to be treated as a valid training and research tool. It will also allow the reconstruction of the course of events for the purpose of trial and scientific evaluation.

6. It will contain a right-hand traffic system functioning as part of the prepared base area. It will also be possible to simulate left-hand traffic if necessary.

7. It will have a database providing different types of terrain: highly urbanised (city centre), suburban and industrial, high altitude (roads with varying degrees of inclination - steep uphill and downhill roads, switchbacks), motorways, expressways, single and dual carriageways, paved (tarmac) and unpaved roads (dirt). The simulated roads will contain all elements of real roads mapped in accordance with the Public Roads Act of 21 March 1985 (i.e. of 23 August 2016, Journal of Laws of 2016, item 1440), including other road elements (specified in the implementing provisions), such as roadsides, sidewalks, intersections, tracks for railway vehicles, horizontal and vertical signs, and traffic lights, other traffic control elements, etc.

8. It will generate lighting for roads and vehicles.

9. It will enable the processing of the scene of the event with the use of IT, communications and other tools (e.g. to measure the braking distance of the vehicle) actually used by the Police when processing the scene.

10. It will enable documenting the work at the scene using the existing report forms.

11. It will enable providing first aid to traffic accident victims. For this purpose, it will be equipped with a set of rescue and training manikins of the highest quality. They will enable the enactment of individually prepared scenarios, including electrocardiography, and the entire process of management will be conducted remotely using a dedicated application. All two manikins will be able to be supervised by the instructor at the same time. They will generate sounds such as breaths. An advanced evaluation module will be implemented, taking into account the needs resulting from the training of groups of people.

12. It will include an instructor module that allows users to easily create their own traffic accident scenarios and save them without any limitations. It will be possible to prepare them in advance, before starting the training. The trainer will have the opportunity to prepare any sets for any training and in this way set, for instance, various levels of difficulty. It will also enable officers, if necessary, to participate in any number of training sessions, and to implement different training scenarios each time. For the purposes of assessing or recreating real situations, 
the trainer will be able to develop scenarios based on any traffic accidents that took place in the past, and develop such a set on the basis of events that will take place in the future. Thanks to this solution the system will never "grow old", and will always be "in demand". It will also have a pre-recorded set of predefined road situations, prepared by road traffic experts, so that it can start training without any additional contribution. The trainer will be able to set the starting situation, and its entire course will be simulated by the system using, among others, experimentally validated vehicle models. The trainees will be able to start their work depending on the training plan - i.e. before, during or after the incident. They will be able to issue commands to virtual participants controlled by a simulation system, e.g. issuing orders to event participants to relocate their cars, secure the scene by cooperating with different services, e.g. the State Fire Service or emergency medical services. If they start their simulated work after the traffic accident, after the exercise the instructor will be able to replay it many times, allowing trainees to watch the course of their actions from any perspective. This will allow them to undergo optimum training in road traffic incidents. The same option will also be possible for activities performed by the trainees. The instructor will be able to add any extra and surprising elements during the exercise - for instance, a vehicle that, without maintaining safety rules or due to an improperly secured scene, will pose a threat to officers working at the scene.

13. It will enable the presentation of the environment to the trainees using images displayed with a high quality projection system through 3D goggles. At the same time, it will be also possible to use the projection system on a flat, spherical or cylindrical screen - the most optimal one will be selected on the basis of tests. The systems can be used interchangeably or at the same time at every stage of the preparation, implementation and evaluation of the exercise. This will allow participation by persons who, for various reasons, cannot use goggles. The instructor will be able to additionally observe the course of the events and further activities performed by the practitioners using $3 \mathrm{D}$ goggles, on the computer screen or directly on the screen used by the practitioners. The system will be designed to minimise the likelihood of simulator sickness in trainees. It will enable the simulation of all possible road incidents using the indicated terrain database and simulated vehicles and objects, generating incidents and enabling their real-time preview at any stage of the exercise, and visualise the entire environment using 3D computer graphics through an optimal projection system (which will be selected on the basis of tests). Consideration is given to standard systems based on high-quality projectors and cylindrical or spherical screens and image display via goggles that allow viewing the digital world in a 360-degree image. The consortium has extensive experience in developing such systems, so the selected solution will meet the requirements for optimising the training process. In addition, the trainees will have the opportunity to perform all the actions necessary to secure the scene and to establish how the incident happened. The simulator will support the participant's assessment process using an automated evaluation system, and will support the subjective assessment process handled directly by the instructor.

The software of the simulation system will be developed in accordance with international HLA (High Level Architecture) standards. This will create in the future the possibility of connecting the computer network of the system under construction with other simulators operating in a shared virtual environment within the interoperability of simulation systems, including the "Integrated simulation platform of crisis management entities" used by the Police in the training process. HLA is a general architecture for distributed computer systems, with particular emphasis on simulation systems. The idea behind HLA is that software applications (computer simulators) can communicate with each other regardless of which platform they have been embedded on. Communication between particular applications is handled by the Runtime Infrastructure (RTI), which plays a similar role to the operating system or virtual machine function. It provides, inter alia: the interoperability of related simulators; the possibility of multiple use simulation system elements; the separation of layers of simulation elements and the layer of auxiliary elements of the environment. HLA uses DIS - Distributed Interface Simulation (a distributed simulation protocol), which is a protocol enabling real-time exercises, defining standard message structures and rules for their exchange (IEEE 1278-1993).

\section{Discussion}

Nowhere in the world do such integrated solutions exist. Nevertheless, thanks to the rapidly evolving simulation technology, there are at least several platforms that can be used in similar areas. However, these are partial solutions with limited (in particular in domestic use) applications and functionalities. Among the solutions existing on the market, the following two systems should be mentioned:

\section{ADMS by ETC (USA) used by:}

- many crisis management centres (or trainers in this field), including NIFV (Nederlands Instituut Fysieke Veiligheid) - Dutch Institute of Physical Security (formerly NIBRA - Dutch Institute of Fire Brigade and Crisis Management), SERCO (British) - International Fire Training Centre, Osceola (USA)

- Florida Crisis Management Office;

- $\quad$ airport emergency services in the USA (including Chicago O'Hare, Minneapolis-St. Paul, Baltimore/ Washington, Nashville);

- counterterrorist units (including Pennsylvania Southeast Region, USA);

- academies and schools of fire service, including in Warwickshire (UK), Orlando (USA) and Cheonan (South Korea). 
2. VBS2 developed by Bohemia Interactive Simulations (Australia) and intended for use by various crisis services, but in practice primarily applicable to military operations and used, among others, by ground armed forces of the USA, Canada, Australia, Great Britain and France.

Among solutions available in Poland, first of all one should mention the Police Simulator of Crisis Situations used by the Police Academy in Szczytno, the Simulator for training supporting command during rescue operations related to fires in multi-story buildings and transport accidents, located in the Main School of Fire Service (both produced as a result of research and development projects financed by the National Centre for Research and Development, by consortium members - WSPol, SGSP and ETC-PZL) and systems supporting land and sea safety management - CZK/CPR simulators produced by Sprint S.A.

The existing standards for the exchange of information between simulators (including HLA or DIS) are generally known and available. However, these standards are primarily intended for flight simulation and do not provide mechanisms to exchange such complex and diverse information as required in the case of the Integrated Platform, and do real-time calculations. Due to the limitations of the HLA standard (primarily the suboptimal, reduced efficiency of information exchange) some simulator manufacturers use their own solutions; however - for understandable reasons - they are not disclosed.

Existing simulators and simulation environments (especially various computer game engines) are focused primarily on the teaching/training of individual operators (the so-called First Person Games), while in the area of such comprehensive training and commanding, no existing solutions are known.

Simulation models of the virtual environment required for the assumed scenarios and controlled by "artificial intelligence" algorithms (e.g. crowd, individual people, forces and units of various services taking part in activities) are not common. A fairly advanced functionality when it comes to the basic scope of requirements is provided by software such as the Presagis $\mathrm{Al}$ Implant, VR-Forces and B-HAVE by MÄK, etc. In the field of simulation of forces and units of other services, currently there are no such solutions that meet the set requirements. In imaging there are graphic libraries providing similar imaging (e.g. Vega Prime). However, they will not simulate all effects that are required.

\section{Applicability of the simulator for training officers of the State Fire Service}

In addition to training Police officers described in the article, the presented simulator has considerable potential for being used to train other uniformed formations, in particular traffic policemen, forensic technicians, and policemen carrying out patrols and intervention tasks. One of them is the State Fire Service. At this point, it is worth noting that the presented functionalities of the simulator allow its use to train officers of the State Fire Service in at least three training areas.

First, the simulator allows trainees to acquire competencies related to the provision of premedical first aid through a module containing a set of rescue and training manikins connected to a virtual environment. This type of training will allow users to feel the emotions accompanying rescuers at the scene (through the visualisation of the scene in the virtual world), while enabling physical performance of rescue operations at the site of the incident.

Another training area concerns the ability to behave properly at the scene of a traffic accident, providing the police officer's perspective. This applies to the ability to see traces, which are important for further procedures related to the forensic examination of the scene, and which allow to reconstruct how the incident happened. The ability to notice these traces is obviously not superior to the duty of saving human life, but such knowledge would help to prevent destroying evidence when processing the scene.

The last training area involves understanding the mechanisms of how a motor vehicle (a car) is damaged during a collision, especially when damage takes place inside it, causing, among others, the victim to be stuck in the vehicle. The ability to simulate the impact of a specific force on a vehicle assigned to specific vehicle speeds is a novelty not found in other training simulators. This competence would allow officers to locate places causing a person to be stuck inside a vehicle faster and more accurately, thereby facilitating their rescue.

\section{Conclusion}

At present, no comprehensive solutions exist, both in Poland and in the world, to support the training process in the proposed way. The implementation of such a tool in the Police training system would help to improve the quality of police officer training, and could have a positive impact on their work environment. The simulator should increase the effectiveness of processing traffic incident scenes.

Introducing the simulator to the Police training system will be one of the ways to reduce its costs. Training of people using the simulator eliminates property damage, and reduces the risk of loss of life and health due to actions taken by insufficiently skilled trainees. Another benefit of using the simulator is the possibility of conducting research in order to assess the impact of factors that may affect the quality of handling traffic accidents. The system may be applied in the development and optimisation of universal, model procedures for police officers at the scene of a traffic accident, and will facilitate a more effective use of their potential. The system will be able to support the selection of candidates for individual positions, preventing the widespread practice of random choices which expose the public to lower safety levels. The simulator will allow the assessment of the mental strain accompanying the performance of tasks by the trainees and individual tests verifying their suitability to perform the tasks. Another element contributing to its importance is the possibility to assess the impact of external factors on the speed and quality of officers' actions in difficult situations. It will also enable professional training of Police intervention officers in handling traffic accidents. Thanks to the applied mathemat- 
ical models and simulation methods, the response of the system to the decisions made by the trainees will be immediate and appropriate to the situation. It will enable repeated exercises of various variants, allowing officers to be fully prepared to perform the tasks assigned to them, creating the potential for knowledge and experience in many areas, far exceeding the possibilities of conventional training.

\section{Literature}

[1] Wojtuszek T., Administracja europejska a bezpieczeństwo w ruchu drogowym, Bielsko-Biała 2013.

[2] Petridou E., Moustaki M., Human factors in the causation of road traffic crashes, "European Journal of Epidemiology" 2000, 16 (9), 819-826, https://doi. org/10.1023/A:1007649804201.

[3] Jurgielewicz M., Nowakowski Z., Rajchel J., Rajchel K., Prawne aspekty bezpieczeństwa ruchu drogowego, Wydawnictwo Wyższej Szkoły Informatyki i Zarządzania i Administracji, Warszawa 2011.

[4] Stefański R.A., Ustawa Prawo o ruchu drogowym. Komentarz, Warszawa 2003

[5] ETSC Report 2018, https://www.its.waw.pl/10270,pl,Statystyki-BRD-w-raporcie-ETSC.html, [dostęp: 08.02.2018].

[6] Goniewicz M., Goniewicz K., Wypadki drogowe w Polsce - czynniki sprawcze i zapobieganie, „Bezpieczeństwo Pracy" 2010, 9, 14-17.

[7] National Police Headquarters, 2018, Traffic accidents - annual reports.

[8] Varhelyi A., Road Safety Management, „The Open Transportation Journal" 2016, 10(1), 137-155, https://doi.org/ $10.2174 / 1874447801610010137$.

MARIUSZ NEPELSKI, PH.D.- security sciences, Lieutenant-Colonel, Professor at the Main School of Fire Service, Director of the Institute for Research and Development at the Police Academy in Szczytno, Senior Police Commissioner. His research and scientific interests involve issues related to internal security, including in particular public security (public order and safety) and common security (crisis management), including modern security technologies. He has been actively involved in a number of research and development projects. Author, co-author and scientific editor of numerous publications about the mentioned subjects, issued in Poland and abroad.
This work was part-funded by the National Centre for Research and Development of Poland under grant DOB-BIO9/06/01/2018. The system is being developed by a consortium of: the Police Academy in Szczytno (Project Leader), the Main School of Fire Service, the Tadeusz Kościuszko Academy of Land Forces, the MORATEX Institute of Safety Technologies and ETC-PZL Aerospace Industries sp. z o.o.

[9] National Road Safety Programme 2013-2020, National Road Safety Council, Warszawa 2013, 7.

[10] Section 1(2) of Ordinance No. 30 of the National Police Commander-in-Chief of 22 September 2017 on performing duty on roads, Official Journal of the National Police Headquarters of 2017 , item 64.

[11] Souza A.M., Brennand C., Yokoyama R, Donato E., Madeira E., Villa L., Traffic management systems: A classification, review, challenges, and future perspectives, "International Journal of Distributed Sensor Networks" 2017, 13(4), https://doi.org/10.1177/1550147716683612.

[12] Merkisz J., Tarkowski S., Wybrane aspekty wykorzystania pokładowych urządzeń rejestrujących w pojazdach samochodowych, „Eksploatacja i Niezawodność” 2011, 2, 50-58.

[13] Kędzierska G., Polskie prawo i kryminalistyka o oględzinach, „Jurisprudencija” 2000, 18(10), 86-93

[14] Wicher J., Pojazdy samochodowe. Bezpieczeństwo samochodów i ruchu drogowego, Wydawnictwa Komunikacji i Łączności WKŁ, Warszawa

[15] Decision No. 472 of the Chief Commander of the Police of 18 November 2013 on the Curriculum of the Specialist Road Traffic Training Course - General Part, Official Journal of the National Police Headquarters item 95.
JAROSŁAW STRUNIAWSKI, PH.D. - the alumnus of the National Defence University and the Police Academy in Szczytno. He was awarded his PhD in Defence at the Management and Command Faculty of the National Defence University in Warsaw in 2012. He conducts national and international research on mass event security. He has actively participated in the training of public administration personnel at the provincial and county level, including PSP (Polish Fire Service), SG (Border Guard), BOR (Government Protection Bureau) and others. Since 1995 he has been professionally affiliated with the Police. His scientific interests include commanding the Police, command work, managing the security of mass events and public assemblies. Author and co-author of numerous scientific articles and three monographs from the field of safety, including the areas mentioned above. He has attended national and international research conferences. 